\section{Gibberellic Acid, Rootstocks, and Post-freeze Fruit Quality of 'Rohde Red' Valencia Oranges}

\author{
Frederick S. Davies ${ }^{1}$ and Glenn Zalman \\ Department of Horticultural Sciences, University of Florida, P.O. Box \\ 110690, Gainesville, FL 32611
}

Additional index words. Citrus sinensis, plant growth regulators, cold hardiness, frost hardiness

\begin{abstract}
The authors' objectives were to determine whether gibberellic acid $\left(\mathbf{G A}_{3}\right)$ initially increases juice content of 'Rohde Red' valencia oranges and prevents or delays decreases in juice content after a freeze, and to determine whether there is an interaction between $\mathbf{G A}_{3}$, rootstock, and juice content. The experiment consisted of a $2\left(+,-\mathbf{G A}_{3}\right) \times 3$ (rootstock) factorial using a completely randomized design with 10 replications per treatment. Gibberellic acid was applied to mature 'Rohde Red' valencia [Citrus sinensis (L.) Osb.] orange trees on three rootstocks-Citrus volkameriana Ten. \& Pasq.(Volk), Swingle citumelo [C. paradisi Macf. $\times$ Poncirus trifoliata $(\mathrm{L}$.) Raf.], and Carrizo citrange $[C$. sinensis $\times P$. trifoliata $]$ at color break in Fall 2002, 2003, and 2004. Juice content, soluble solids content (SSC), titratable acidity (TA), ratio of SSC to TA, and kilogram solids per box were determined at about 2 -week intervals after several freezes. In 2002 03 and 2004-05, juice content in the fall was greater and the rate of decrease in juice content lower for $\mathrm{GA}_{3}$-treated fruit than nontreated fruit for about 8 weeks after a freeze. In contrast, in 2003-04, juice content and rate of decrease in juice content were not different between treatments. Juice content was lower for fruit from 'Rohde Red' trees on Volk compared with those on Carrizo and Swingle, and more important, the rate of decrease in juice content after a freeze was greatest for trees on Volk in all three seasons. Soluble solids content, TA, SSC-to-TA ratio, and kilogram solids generally were not effected by $\mathrm{GA}_{3}$ treatment. Therefore, $\mathrm{GA}_{3}$ application at color break in the fall generally increased juice content and slowed the rate of decrease in juice content after a freeze compared with nontreated fruit. In addition, juice content differed significantly with rootstock, but there was no $\mathrm{GA}_{3} \times$ rootstock interaction.
\end{abstract}

Gibberellic acid $\left(\mathrm{GA}_{3}\right)$ has been applied to citrus fruit since the 1950 s to delay peel senescence and prolong on-tree storage (Coggins, 1981; Davies, 1986; El-Otmani et al., 2000). Application of $\mathrm{GA}_{3}$ does not typically affect internal fruit quality (Coggins, 1981; Davies, 1986). However, several studies have shown that $\mathrm{GA}_{3}$ application in the fall increased juice content of 'Pineapple' oranges by $2 \%$ to $10 \%$ (Davies, et al., 1997, 1999), and 'Hamlin' oranges by as much as $15.1 \%$ (Davies and Zalman, 2006). This increase in juice content appears to be related to decreases in peel volume (Fidelibus et al., 2002), rather than to changes in extraction efficiency during juicing as a function of rheological changes in the fruit (Fidelibus et al., 2002).

Gibberellic acid also affects freeze hardiness of citrus trees in some cases. Cooper and Peynado (1958) applied $100 \mathrm{mg} \cdot \mathrm{L}^{-1} \mathrm{GA}_{3}$ to grapefruit trees in Texas in the fall and observed that these trees produced growth flushes earlier than nontreated trees. This early growth flush made the trees more

Received for publication 6 Dec. 2006. Accepted for publication $22 \mathrm{Feb} .2007$.

${ }^{1}$ To whom reprint requests should be addressed; e-mail fsd@ufl.edu susceptible to freeze damage. Similarly, Young (1971) applied several plant growth regulators including $\mathrm{GA}_{3}$ to grapefruit trees in Texas. He found that $\mathrm{GA}_{3}$ increased cambial activity and shoot growth, which led to more freeze damage than for nontreated trees. In contrast, Davies and Zalman (2006) observed no effect of $\mathrm{GA}_{3}$ on freeze hardiness of 'Hamlin' orange trees in north central Florida. Differences in response to $\mathrm{GA}_{3}$ could be related to higher winter temperatures in south Texas than in north Florida, which caused trees to deacclimate sooner, thus becoming more sensitive to freeze damage.

It has long been known that juice content of citrus decreases after a freeze because damaged fruit sections do not rehydrate, but instead lose water through the peel (Syvertsen, 1982). Juice content decreased by as much as $25 \mathrm{U}$ (i.e., $58 \%$ to $33 \%$ ) within 2 weeks after a freeze, causing a reduction in kilogram solids [soluble solids content $(\mathrm{SSC}) \times$ juice content] and net returns to growers (Rasmussen et al., 1963). Davies and Zalman (2006) also found that fruit temperatures of $-6.1{ }^{\circ} \mathrm{C}$ for $4 \mathrm{~h}$ decreased postfreeze juice content of 'Hamlin' oranges from $52.2 \%$ to $27.8 \%$ during an 8 -week period, but the effect was not consistent. Furthermore, they observed that application of $\mathrm{GA}_{3}$ slowed the rate of decrease in juice content after a freeze in some cases.
Several factors are involved with freezing of citrus fruit, including minimum temperature and duration, species (Hendershott, 1962), peel thickness (Carter and Barros, 1984; Hendershott, 1962), and fruit maturity (Calvert, 1977; Carter and Barros, 1984). Rootstocks also affected the extent of freeze damage during the Jan. 1977 freeze in Florida (Calvert, 1977). 'Pineapple' orange fruit on Rangpur lime and rough lemon rootstocks showed an $8.2 \%$ greater loss in juice content after a freeze than observed in four other rootstocks. These differences, however, may have been related to the inherently lower SSC for fruit on these two rootstocks than on the other four rootstocks and not to differences in responses to freezing.

Therefore, there are possible associations between sweet orange fruit juice content, $\mathrm{GA}_{3}$, rootstock, and fruit freezing. The primary objective of this study was to determine whether $\mathrm{GA}_{3}$ and rootstock affect prefreeze juice content, and freezing pattern and internal quality of 'Rohde Red' valencia orange fruit over time after a freeze. A second objective was to determine whether there is an interaction between $\mathrm{GA}_{3}$ and rootstock related to juice content and freeze hardiness.

\section{Materials and Methods}

Plant materials. Bare-root 'Rohde Red' valencia orange nursery trees on Carrizo citrange, Swingle citrumelo, and Citrus volkameriana rootstocks were planted in May 1995 at a $2.4 \times 6.1-\mathrm{m}$ within- and betweenrow spacing in Gainesville, Fla. Trees were originally part of a nutrition-rootstock study conducted from 1995-2000 (Davies and Zalman, 2001). In Spring 2000, 20 trees of each rootstock were selected from the optimum fertilization and irrigation treatments from the previous study. These trees had all been exposed to the same cultural practices for the previous five seasons.

Treatments. Pro-Gibb (GA $\mathrm{GA}_{3}$; Abbott Laboratories, Chicago) was applied to 10 trees on each rootstock on 21 Nov. 2002 at an equivalent of $45 \mathrm{~g} \cdot \mathrm{ha}^{-1}$ a.i. $+0.05 \%$ Silwet using a Solo Backpack sprayer (Solo, Newport News, Va.) at $2 \mathrm{~L} /$ tree. Fruit were at the color break stage (hue, $\approx 110^{\circ}$ ). Ten trees on each rootstock were not sprayed. The treatments were repeated using the same trees on $3 \mathrm{Dec}$. 2003 and 10 Dec. 2004. Multiple applications of $\mathrm{GA}_{3}$ have no affect on tree health, vigor, or yields (Davies and Zalman, 2006; Fidelibus et al., 2002).

Temperature measurements. Copperconstantin T-type thermocouples were attached to leaves, fruit, and limbs of one tree/quadrant in the 0.24-ha experimental plot. Thermocouples were attached to the underside of leaves and limbs and to the proximal side of the fruit using plastic tape to prevent direct exposure to the sky. Sheltered air temperatures were also recorded at a $1.37-\mathrm{m}$ height in each quadrant. Temperatures were recorded hourly during each freeze night using a Doric 245 Digitrend recorder (InterTechnology, Don Mills, Ont., Canada). 
Fruit quality measurements. Fruit were harvested about every 2 weeks after several moderate to severe freezes in each of three seasons. Fruit were harvested on 8 Jan., 28 Jan., 11 Feb., 25 Feb., and 11 Mar. 2003; 12 Jan., 26 Jan., 9 Feb., 23 Feb., and 8 Mar. 2004; and 8 Jan., 21 Jan., 4 Feb., 18 Feb., and 4 Mar. 2005. Ten fruit were harvested around the canopy of each tree in 2003, and 20 fruit were harvested in 2004 and 2005 at a $0.91-$ to $1.82-\mathrm{m}$ height (Reitz and Sites, 1948). Fruit sample size was increased in 2004 and 2005 because yields were greater than in 2003 and more fruit were available. Fruit were weighed and juiced on an FMC Fresh and Squeeze juicer (FMC, Lakeland, Fla.), and the percent juice was determined. Juice-corrected SSC was determined using a refractometer with appropriate correction factors for titratable acidity (TA; Bellingham and Stanley, Tunbridge Wells, UK), which was determined by standard methods using an automatic titrator (Denver Instruments, Denver). The ratio of SSC to TA and kilogram solids/box (SSC $\times$ juice content) were then calculated (Wardowski et al., 1995).

Experimental design and statistical analysis. The experiment was arranged as a 2 $\left(+\mathrm{GA}_{3},-\mathrm{GA}_{3}\right) \times 3$ (rootstock; Swingle, Carrizo, Volk) factorial using a completely randomized design with 10 single-tree replications/treatment. Fruit were harvested at five dates as described earlier, and data were initially analyzed by analysis of variance to determine main effects and interactions. Changes in fruit quality factors over time were analyzed by regression analysis within each year using Sigma Plot v.10.0 software (SYSTAT Software, Richmond, Calif.).

\section{Results and Discussion}

\section{Season 1, 2002-03}

Temperatures. On 7-8 Jan. 2003, minimum air temperature reached $-2.7^{\circ} \mathrm{C}$ for $3 \mathrm{~h}$, with $7 \mathrm{~h}$ less than $0{ }^{\circ} \mathrm{C}$. Ice was observed in $\approx 10 \%$ of the fruit based on a $6.35-\mathrm{mm}$ cut at the stem end (Wardowski et al., 1995). A severe freeze occurred on 23-24 Jan., with a minimum sheltered air temperature of $-6.1^{\circ} \mathrm{C}$ for $4 \mathrm{~h}$, with $14 \mathrm{~h}$ less than $0{ }^{\circ} \mathrm{C}$. Fruit were frozen throughout after this freeze (i.e., hard ice was found in the center of the fruit). A freeze with this minimum temperature and duration generally causes moderate to severe fruit damage (Davies and Zalman, 2006; Hendershott, 1962).

Fruit quality. The entire data set was analyzed for main effects and interactions. Date (harvest time), treatment, and rootstock had highly significant effects on juice content $(P<0.01)$. There was a date $\times$ treatment interaction, but treatment effects were nonsignificant only on date 1 ( 8 Jan.). There were no other significant interactions for any fruit quality factor (SSC, TA, SSC-to-TA ratio, kilogram solids per box). Data were then analyzed via regression analysis by date and fruit quality factor beginning before the freeze and continuing for about 8 weeks thereafter.

Juice content for $\mathrm{GA}_{3}$-treated trees was significantly $(P<0.05)$ greater than that of nontreated trees at every postfreeze harvest date (Fig. 1). The moderate freeze of 7-8 Jan.

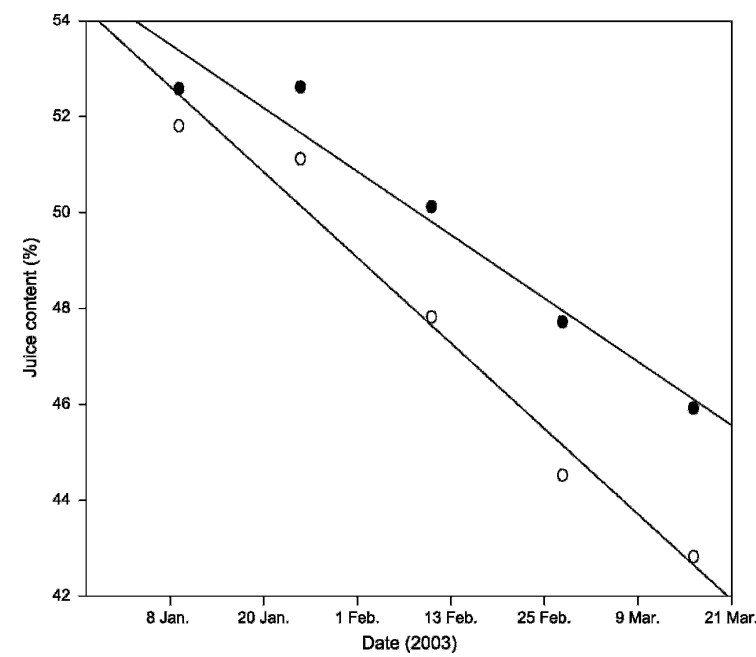

Fig. 1. Effects of gibberellic acid $\left(\mathrm{GA}_{3}\right)$ and fruit freezing on juice content of 'Rohde Red' valencia orange fruit after freezes in 2002-03. $O$, nontreated, $\mathrm{y}=52.45-0.18 \mathrm{x}, r^{2}=0.92 ; \mathbf{O}, \mathrm{GA}_{3}$ treated, $\mathrm{y}=53.51-$ $0.13 \mathrm{x}, r^{2}=0.95 ; \mathrm{n}=10$ trees $/$ date.

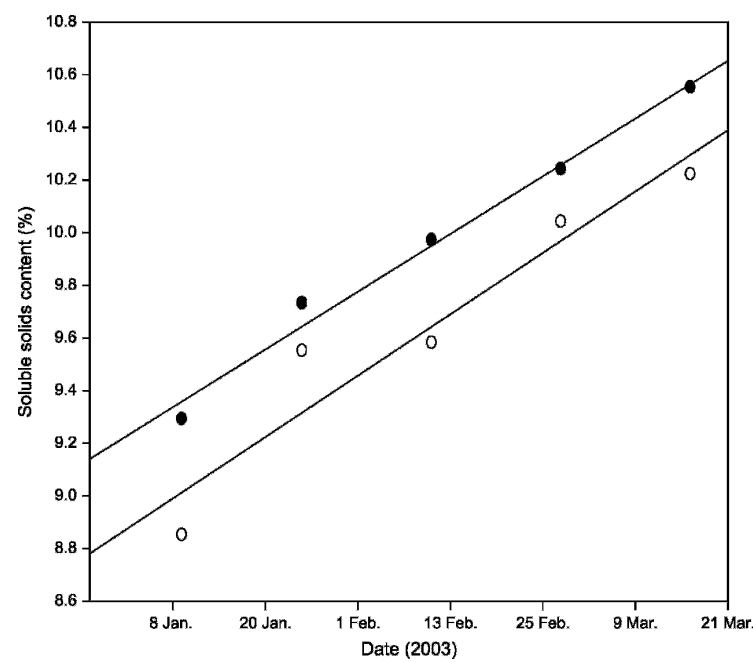

Fig. 2. Effects of gibberellic acid $\left(\mathrm{GA}_{3}\right)$ and fruit freezing on soluble solids content of 'Rohde Red' valencia orange fruit after freezes in 2002-03. $\bigcirc$, nontreated, $\mathrm{y}=8.99+0.023 \mathrm{x}, r^{2}=0.92 ; \boldsymbol{\bullet}, \mathrm{GA}_{3}$ treated, $\mathrm{y}=9.34+0.021 \mathrm{x}, r^{2}=0.98 ; \mathrm{n}=10$ trees/date.

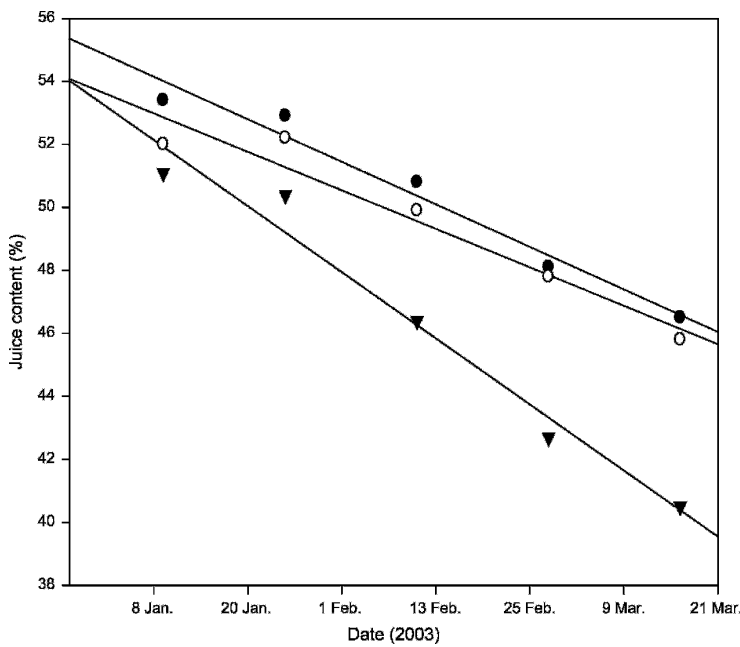

Fig. 3. Effects of gibberellic acid and fruit freezing on juice content of 'Rohde Red' valencia orange fruit on three rootstocks after freezes in 2002-03. - , Swingle, $\mathrm{y}=54.14-0.13 \mathrm{x}, r^{2}=0.97 ; \bigcirc$, Carrizo, $\mathrm{y}=52.98-0.12 \mathrm{x}, r^{2}=0.94 ;(\boldsymbol{\nabla})$ Volk, $\mathrm{y}=52.13-0.21 \mathrm{x}, r^{2}=0.97 ; \mathrm{n}=10$ trees/date. 
(minimum temperature, $-2.7{ }^{\circ} \mathrm{C}$ for $2 \mathrm{~h}$ ) and the severe freeze of 24 Jan. (minimum temperature, $-6.1{ }^{\circ} \mathrm{C} ; \quad<0{ }^{\circ} \mathrm{C}$ for $14 \mathrm{~h}$ ) decreased juice content for $\mathrm{GA}_{3}$-treated fruit from $52.6 \%$ to $45.9 \%$, and for nontreated fruit from $51.1 \%$ to $42.8 \%$. There was a highly significant $(P<0.01)$ linear decrease in juice content for both treatments over time. The rate of decline in juice content was greater for the nontreated fruit compared with $\mathrm{GA}_{3}$ treated fruit. Similar patterns of decreases in juice content were observed after the Mar. 1980 freeze in Florida (Carter, 1980) and during the same season (2003) for 'Hamlin' oranges (Davies and Zalman, 2006). The $\mathrm{GA}_{3}$-induced increase in juice content in this study occurred much earlier in the season than previously observed with 'Valencia' oranges (Fidelibus et al., 2002), and the effect was more consistent and persisted for about 8 weeks after the freeze. Gibberellic acid increased juice content over control values from $1.5 \%$ in January to $7.2 \%$ in March.

Application of $\mathrm{GA}_{3}$ in November did not significantly affect juice overall SSC, TA, or the ratio of SSC to TA (data not shown). Soluble solids content gradually increased from 8 Jan. (8.85\%) to 11 Mar. (10.22\%) for nontreated fruit and from $9.29 \%$ to $10.55 \%$ for $\mathrm{GA}_{3}$-treated fruit (Fig. 2). The slopes of the lines were not significantly different $(P<$ $0.05)$. Titratable acidity levels gradually decreased and the SSC-to-TA ratio increased from 8 Jan. to 11 Mar. (data not shown). These results are similar to those observed by Carter (1980) for 'Valencia' oranges after the Mar. 1980 freeze in Florida, but differ from those of Calvert (1977), who observed a slight decrease in SSC after the Jan. 1977 freeze in Florida. Application of $\mathrm{GA}_{3}$ in November also significantly increased kilogram solids per box $(40.5 \mathrm{~kg})$ over those of nonsprayed fruit by as much as $10.2 \%$ on 11 Mar. This is one of the few times that $\mathrm{GA}_{3}$ has produced a consistent increase in kilogram solids per box (Davies et al., 1997; Davies and Zalman, 2006). Generally, statistically significant changes in kilogram solids per box are difficult to document because SSC and juice content often vary independently, and the product of the two is often similar (Davies and Zalman, 2004; Reitz and Sites, 1948).

There were also large differences in juice content (Fig. 3) and SSC (Fig. 4) among rootstocks independent of the $\mathrm{GA}_{3}$ treatment. Juice content was the same for fruit from trees on Swingle and Carrizo rootstocks, which were greater than for those on Volk at all harvest dates except $8 \mathrm{Jan} .(P<0.05)$. In addition, percentage decrease in postfreeze juice content from 8 Jan. to 11 Mar. was much greater for fruit from trees on Volk (20.7\%) compared with those on Swingle (12.9\%) or Carrizo (11.9\%). Typically fruit from trees on Volk have a lower juice content than those on Swingle or Carrizo (Castle, 1987). Calvert (1977) also observed a greater reduction in juice content after a freeze for trees on Rangpur lime and rough lemon than on other rootstocks. He attributed this greater decline in juice content after a freeze to the

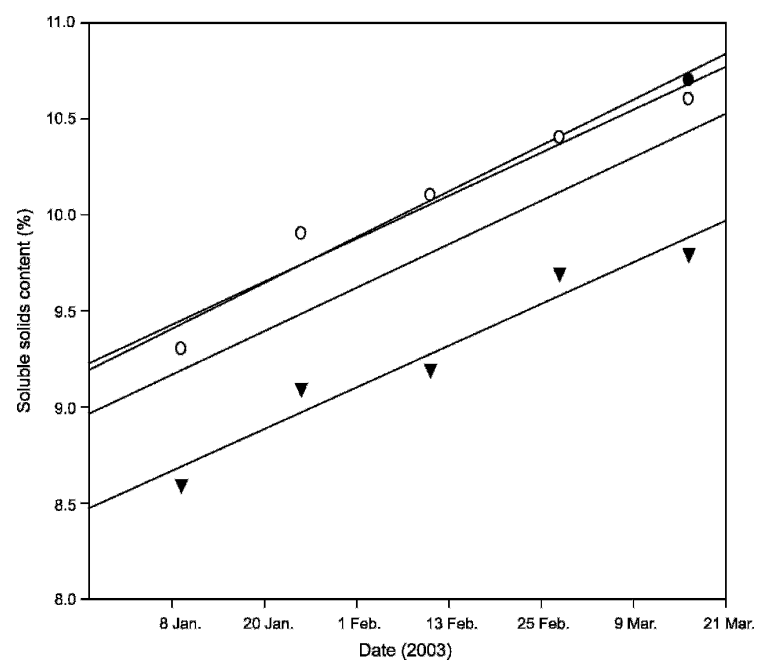

Fig. 4. Effects of gibberellic acid and fruit freezing on soluble solids content of 'Rohde Red' valencia orange fruit on three rootstocks after freezes in 2002-03. - , Swingle, $\mathrm{y}=9.40-0.023 \mathrm{x}, r^{2}=0.96$; $\bigcirc$, Carrizo, $\mathrm{y}=9.42-0.022 \mathrm{x}, r^{2}=0.94 ;(\boldsymbol{\nabla})$ Volk, $\mathrm{y}=8.66-0.021 \mathrm{x}, r^{2}=0.94 ; \mathrm{n}=10$ trees $/$ date.

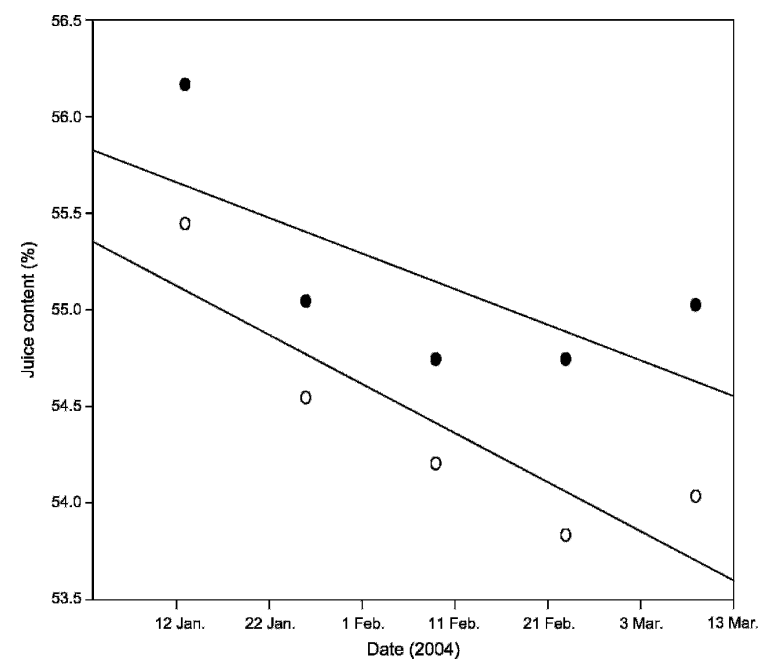

Fig. 5. Effects of gibberellic acid $\left(\mathrm{GA}_{3}\right)$ and fruit freezing on juice content of 'Rohde Red' valencia orange fruit after freezes in 2003-04. $O$, nontreated, $\mathrm{y}=55.12-0.025 \mathrm{x}, r^{2}=0.77 ; 0, \mathrm{GA}_{3}$ treated, $\mathrm{y}=55.65-$ $0.01 \mathrm{x}, r^{2}=0.47 ; \mathrm{n}=10$ trees/date.

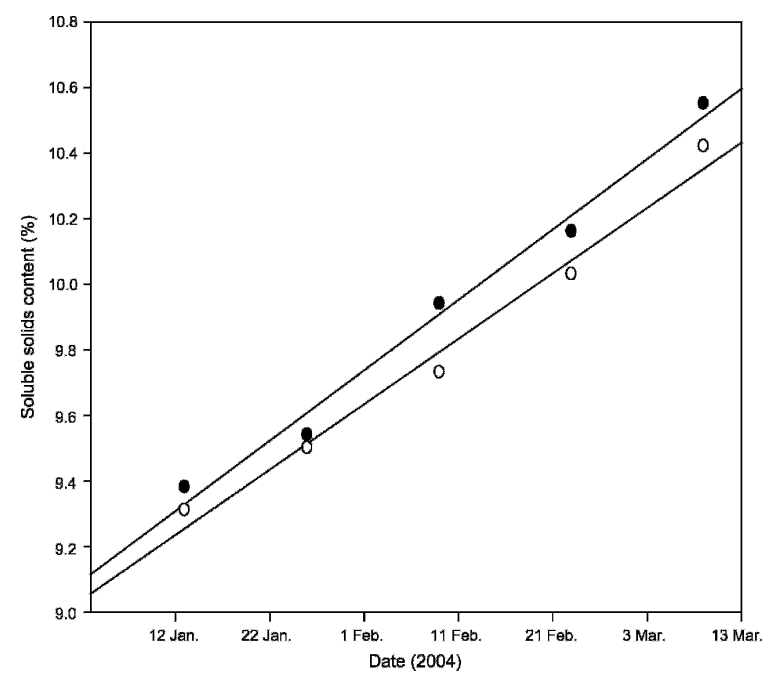

Fig. 6. Effects of gibberellic acid $\left(\mathrm{GA}_{3}\right)$ and fruit freezing on soluble solids content of 'Rohde Red' valencia orange fruit after freezes in 2003-04. $O$, nontreated, $\mathrm{y}=9.23-0.19 \mathrm{x}, r^{2}=0.98 ; \boldsymbol{\bullet}, \mathrm{GA}_{3}$ treated, $\mathrm{y}=9.31+0.021 \mathrm{x}, r^{2}=0.98 ; \mathrm{n}=10$ trees/date. 
lower SSC for trees on these lemon-type rootstocks. Soluble solids content level in the juice is known to affect fruit freeze characteristics (Carter and Barros, 1984). We also found a lower mean SSC for trees on Volk compared with those on Carrizo and Swingle, which is well-known (Castle, 1987), and SSC content increased over time after the freezes (Fig. 4). Therefore, our data are in agreement with those of Calvert (1977) from the Jan. 1977 freeze in Florida.

The same general trend related to rootstock occurred for kilogram solids per box and TA (data not shown). Both factors were higher for fruit from trees on Swingle and Carrizo than those on Volk for all harvest dates except 8 Jan. $(P<0.05)$. Fruit from trees on Volk typically have lower kilogram solids per box and TA than those on Swingle or Carrizo (Castle, 1987). The SSC-to-TA ratio, however, was not significantly different for any rootstock or harvest date (data not shown). This is somewhat surprising, because SSC and TA often differed among rootstocks. However, results are similar to those observed previously (Davies and Zalman, 2004; Reitz and Sites, 1948).

\section{Season 2, 2003-04}

Temperatures. In 2003-04 there were 10 dates when temperatures were less than $0{ }^{\circ} \mathrm{C}$. However, moderate freezes occurred only on 20 Dec. 2003 , with $10 \mathrm{~h}$ less than $0{ }^{\circ} \mathrm{C}$ and a minimum temperature of $-3.3{ }^{\circ} \mathrm{C}$ for $3 \mathrm{~h}$, and on 29 Jan., with $6 \mathrm{~h}$ less than $0{ }^{\circ} \mathrm{C}$ and a minimum temperature of $-3.8^{\circ} \mathrm{C}$ for $1 \mathrm{~h}$.

Fruit quality. The entire data set was analyzed for main effects and interactions. Date (harvest time), treatments, and rootstock again had highly significant effects on juice content $(P<0.01)$. There was no interaction between date and treatment and rootstock and treatment in the overall analysis. In addition, there were no significant interactions for any other fruit quality factor (SSC, TA, SSC-to-TA ratio, kilogram solids per box). Data were then analyzed via regression for harvest date (time after a freeze) and fruit quality factor beginning prefreeze and continuing for about 8 weeks thereafter.

Unlike in 2002-03, juice content was not significantly different within each date for $\mathrm{GA}_{3}$-treated and nontreated fruit, but it was always numerically higher for the $\mathrm{GA}_{3}$ treatment (Fig. 5). Moreover, $\mathrm{GA}_{3}$ application increased juice content by only $1.8 \%$, which is much lower than observed previously (Davies and Zalman, 2006). The decline in juice content over time was also much less than observed in 2002-03, possibly because of less fruit exposure to critical, damaging temperatures. In addition, $r^{2}$ values were far lower in 2003-04 than in 2002-03, again likely because minimum temperatures and duration of the freeze were borderline for fruit damage (Hendershott, 1962). Therefore, in a population of fruit on the same tree, some would be above and some below the damage threshold, depending on their location in the tree (Wilcox and Davies, 1981). This variation

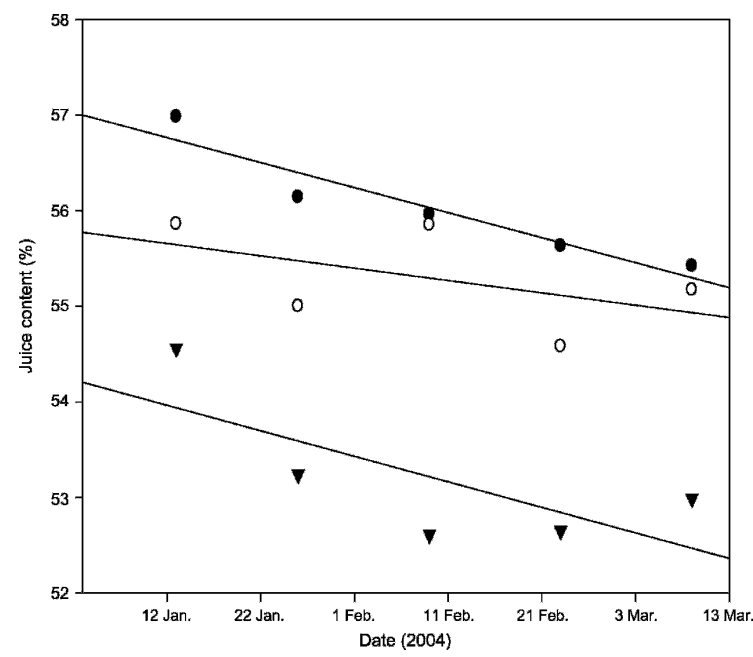

Fig. 7. Effects of gibberellic acid and fruit freezing on juice content of 'Rohde Red' valencia orange fruit on three rootstocks after freezes in 2003-04. - Swingle, $y=56.76-0.026 x, r^{2}=0.90 ; \bigcirc$, Carrizo, $\mathrm{y}=55.65-0.013 \mathrm{x}, r^{2}=0.25 ;(\boldsymbol{\nabla})$ Volk, $\mathrm{y}=53.96-0.026 \mathrm{x}, r^{2}=0.53 ; \mathrm{n}=10$ trees/dates.

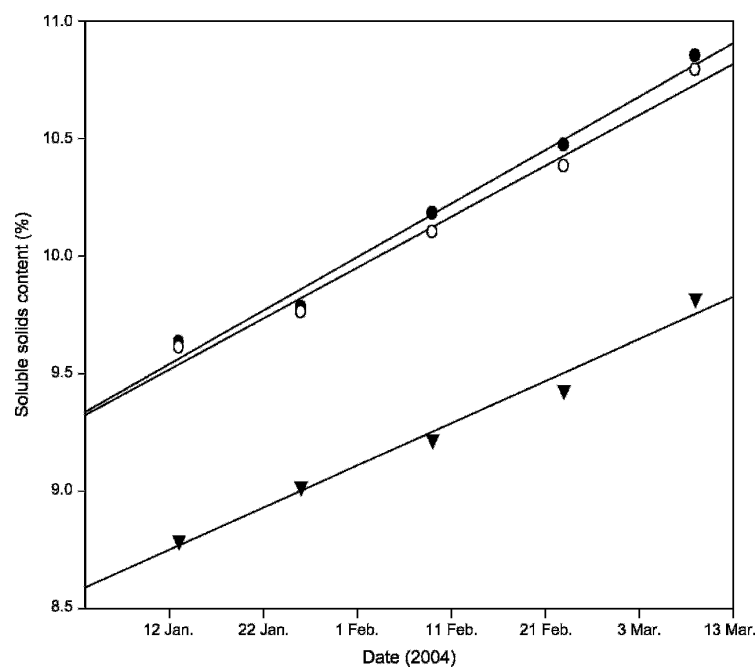

Fig. 8. Effects of gibberellic acid and fruit freezing on soluble solids content of 'Rohde Red' valencia orange fruit after freezes in 2003-04. $\bullet$, Swingle, $\mathrm{y}=9.51-0.021 \mathrm{x}, r^{2}=0.98 ; \bigcirc$, Carrizo, $\mathrm{y}=9.54-$ $0.023 \mathrm{x}, r^{2}=0.98 ;(\boldsymbol{\nabla})$ Volk, $\mathrm{y}=8.75-0.017 \mathrm{x}, r^{2}=0.98 ; \mathrm{n}=10$ trees/dates.

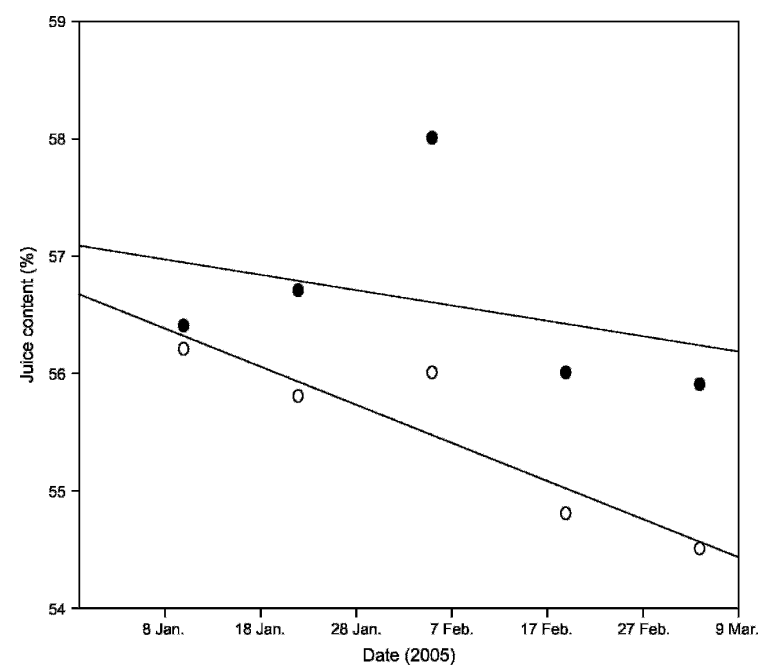

Fig. 9. Effects of gibberellic acid $\left(\mathrm{GA}_{3}\right)$ and fruit freezing on juice content of 'Rohde Red' valencia orange fruit after freezes in 2004-05. $\bigcirc$, nontreated, $\mathrm{y}=56.38-0.064 \mathrm{x}, r^{2}=0.84 ; \boldsymbol{\bullet}, \mathrm{GA}_{3}$ treated, $\mathrm{y}=56.97+$ $0.026 \mathrm{x}, r^{2}=0.11 ; \mathrm{n}=10$ trees/date. 
in fruit temperatures would lead to high withintree variation and low $r^{2}$ values as observed.

Gibberellic acid application also had no significant effect on SSC, and the general increase in SSC over time was similar to that in 2002-03 (Fig. 6). Gibberellic acid did not significantly affect TA, kilogram solids per box, or the SSC-to-TA ratio (data not shown).

There were, however, large significant differences $(P<0.05)$ in juice content (Fig. 7) and SSC (Fig. 8) among rootstocks. Juice content was greatest and similar for fruit on Swingle and Carrizo, and lowest for fruit on Volk. The decrease in juice content over time was less than that observed in 2002-03, and $r^{2}$ values were much lower for fruit on Carrizo and Volk. Soluble solids content was higher for fruit from trees on Swingle and Carrizo than from those on Volk, and the pattern of increase and $r^{2}$ values were similar between the two seasons.

\section{Season 3, 2004-05}

Temperatures. In 2004-05, there were five dates when air and fruit temperatures were less than $0{ }^{\circ} \mathrm{C}$. The minimum air temperature fell to $-3.9{ }^{\circ} \mathrm{C}$ for only $1 \mathrm{~h}$ on 26 Jan. 2005, with $8 \mathrm{~h}<0{ }^{\circ} \mathrm{C}$. This minimum temperature and duration caused only minor fruit damage, as indicated by sequentially cutting fruit after the freeze (data not shown) (Wardowski et al., 1995).

Fruit quality. The entire data set was analyzed for main effects and interactions. Date (harvest time) and rootstock again had highly significant effects on juice content $(P<0.01)$, but treatment did not. There was no interaction between date and rootstock in the overall analysis. There were no significant interactions for any other fruit quality factor (SSC, TA, SSC-to-TA ratio, kilogram solids per box).

Further analysis indicated that juice content was significantly higher for $\mathrm{GA}_{3}$-treated fruit compared with nontreated fruit on 15 Feb. and 15 Mar. $(P<0.05)$ only, and juice content of $\mathrm{GA}_{3}$-treated fruit was highly variable (Fig. 9). Nevertheless, the rate of decrease in juice content over time was greater for nontreated fruit than for $\mathrm{GA}_{3}$ treated fruit, as was the case in the 2002-03 season. Juice content decreased from $56.2 \%$ to $54.4 \%$ for the nontreated fruit and from $56.4 \%$ to $55.9 \%$ for $\mathrm{GA}_{3}$-treated fruit.

Gibberellic acid application had no affect on juice SSC, which increased over the course of the experiment from $9.21 \%$ to $10.33 \%$ for $\mathrm{GA}_{3}$-treated fruit and $9.30 \%$ to $10.15 \%$ for the nontreated fruit (Fig. 10). There were no significant differences within harvest dates in TA, SSC-to-TA ratio, or kilogram solids per box (data not shown).

There were again large significant differences in juice content (Fig. 11) and SSC (Fig. 12) among rootstocks, and there were no rootstock $\times$ treatment interactions. Juice content was similar for fruit from trees on Swingle and Carrizo, which were greater than those for fruit on Volk. Soluble solids content was also similar for fruit from trees on Swingle and Carrizo, and again greater than SSC from fruit with Volk as a rootstock

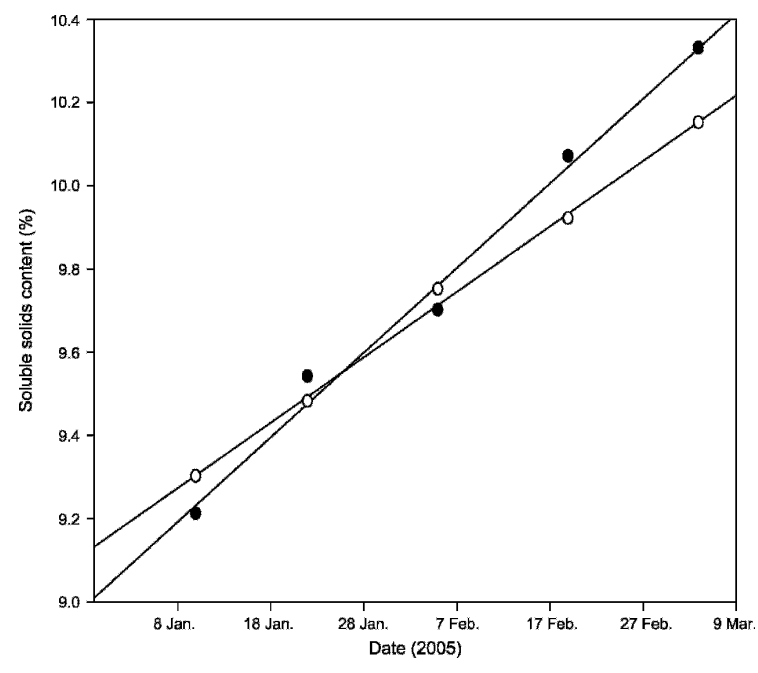

Fig. 10. Effects of gibberellic acid $\left(\mathrm{GA}_{3}\right)$ and fruit freezing on soluble solids content of 'Rohde Red' valencia orange fruit after freezes in 2004-05. $\bigcirc$, nontreated, $\mathrm{y}=9.27+0.03 \mathrm{x}, r^{2}=0.99 ; 0, \mathrm{GA}_{3}$ treated, $\mathrm{y}=9.19+0.04 \mathrm{x}, r^{2}=0.98 ; \mathrm{n}=10$ trees/date.

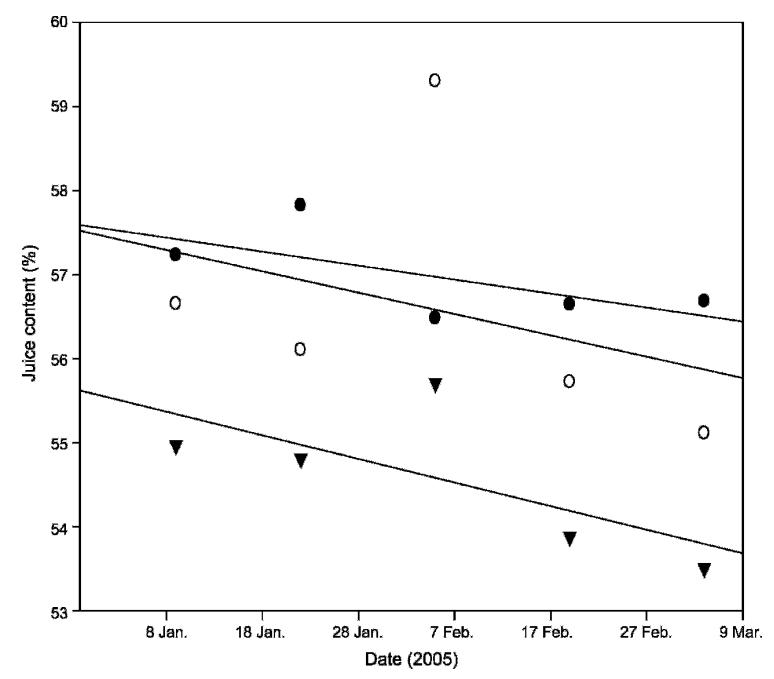

Fig. 11. Effects of gibberellic acid and fruit freezing on juice content of 'Rohde Red' valencia orange fruit on three rootstocks after freezes in 2004-05. - , Swingle, $\mathrm{y}=57.3-0.016 \mathrm{x}, r^{2}=0.43$; $\bigcirc$, Carrizo, $\mathrm{y}=57.3-0.025 \mathrm{x}, r^{2}=0.11 ;(\boldsymbol{\nabla})$ Volk, $\mathrm{y}=55.36-0.028 \mathrm{x}, r^{2}=0.48 ; \mathrm{n}=10$ trees/date.

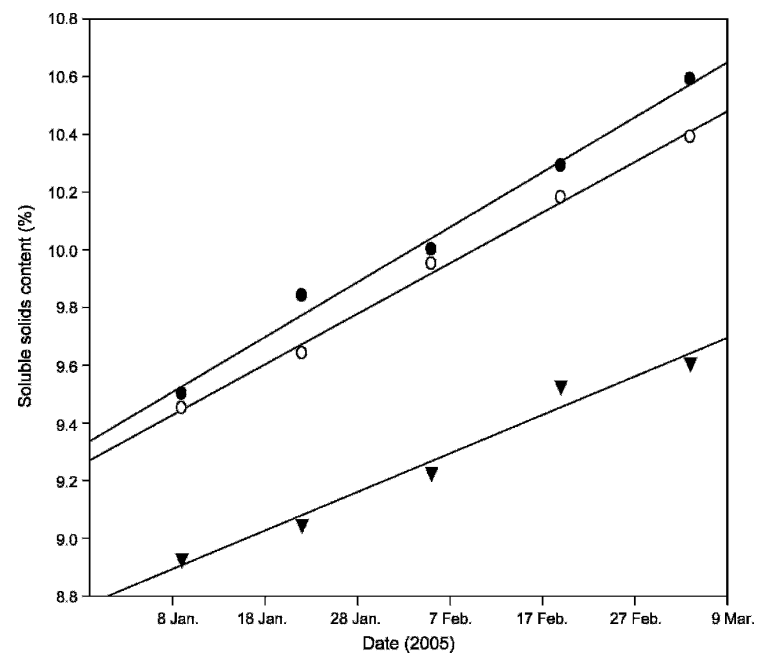

Fig. 12. Effects of gibberellic acid and fruit freezing on soluble solids content of 'Rohde Red' valencia orange fruit on three rootstocks after freezes in 2004-05. Swingle, $\mathrm{y}=9.50+0.020 \mathrm{x}, r^{2}=0.98$ $\mathrm{O}$, Carrizo, $\mathrm{y}=9.43+0.017 \mathrm{x}, r^{2}=0.99 ;(\boldsymbol{\nabla})$ Volk, $\mathrm{y}=8.89+0.013 \mathrm{x}, r^{2}=0.97 ; \mathrm{n}=10$ trees $/$ date 
$(P<0.05$; Fig. 12). These same trends occurred during the two previous seasons.

The same trends related to rootstock occurred for TA and kilogram solids per box (data not shown). Both factors were highest for fruit from trees on Swingle and Carrizo and lowest for fruit on Volk. The SSC-to-TA ratio was not significantly different among rootstocks (data not shown).

Our hypothesis that $\mathrm{GA}_{3}$ increases juice content and slows the rate of decrease in juice content after a freeze was valid in two of three seasons. We speculate that $\mathrm{GA}_{3}$ improves peel integrity and may decrease the rate of postfreeze water loss compared with nontreated peels. Gibberellic acid consistently increased juice content over nontreated fruit by $1.5 \%$ to $7.2 \%$, which is within the ranges reported previously (Davies and Zalman, 2006; Davies et al., 1997, 1999). Consequently, $\mathrm{GA}_{3}$-treated fruit could be harvested over a longer period of time than nontreated fruit after a freeze without extensive losses in juice content. Davies and Zalman (2006) observed similar but less consistent effects of $\mathrm{GA}_{3}$ on the rate of decrease in juice content of 'Hamlin' oranges during the same freezes.

Of interest, rootstock had much more influence on juice content than $\mathrm{GA}_{3}$ treatment. In 2003, fruit from trees on Carrizo and Swingle had from $4.5 \%$ to $14.7 \%$ greater juice content than fruit on Volk within a given date. In contrast, during the 2004 and 2005 seasons, fruit from trees on Carrizo and Swingle had only $4.5 \%$ to $6.3 \%$ higher juice content than fruit on Volk.

Moreover, it appears that rootstock not only affects juice content, but also the rate of decrease in postfreeze juice content over time, as observed by Calvert (1977). This difference may be the result of differences in fruit SSC as observed by Calvert (1977).

\section{Conclusion}

Gibberellic acid application to 'Rohde Red' valencia orange fruit at color break in the fall increased juice content by $1.5 \%$ to $7.2 \%$ in two of three seasons. There was generally no strong interaction between $\mathrm{GA}_{3}$, rootstock, and date (except in 2002-03). Moreover, $\mathrm{GA}_{3}$ did not typically affect SSC, TA, ratio of SSC-to-TA, or kilogram solids content of the fruit, which is similar to that observed for 'Hamlin' oranges (Davies and Zalman, 2006). However, rootstock had a significant effect on juice content and SSC. Fruit from trees on Swingle and Carrizo had much higher juice content than those on Volk. Furthermore, the rate of decrease in juice content after a severe freeze was much greater for fruit on Volk compared with the other two rootstocks. Therefore, the most practical way to increase juice content of oranges before and after freezing is to choose Swingle or Carrizo rootstocks along with $\mathrm{GA}_{3}$ application at color break in the fall.

\section{Literature Cited}

Calvert, D.V. 1977. Changes following the freeze of Jan. 1977 in the quality of fruit and foliage injury from twelve citrus rootstock-scion combinations. Proc. Fla. State Hort. Soc. 90:58-60.

Carter, R.D. 1980. Yield loss in commercially extracted 'Valencia' orange juice following freezing weather. Proc. Fla. State Hort. Soc. 93:55-59.

Carter, R.D. and S.M. Barros. 1984. Freeze effects on juice yield and other characteristics of 'Valencia' orange and 'Marsh' grapefruit. Proc. Fla. State Hort. Soc. 97:89-91.

Castle, W.S. 1987. Citrus rootstocks, p. 361-399. In: R.C. Rom and R.F. Carlson (eds.). Rootstocks for fruit crops. Wiley, New York.

Coggins, C.W., Jr. 1981. The influence of exogenous growth regulators on rind quality and internal quality of citrus fruits. Proc. Intl. Soc. Citriculture 1:214-216.

Cooper, W.C. and A. Peynado. 1958. Effect of gibberellic acid on growth and dormancy in citrus. Proc. Amer. Soc. Hort. Sci. 72:284-289.

Davies, F.S. 1986. Growth regulator improvement of post-harvest quality, p. 79-99. In: W. Wardowski, NagyS., and W. Grierson (eds.). Fresh citrus fruit. AVI Press, Westport, Conn.

Davies, F.S., C.A. Campbell, and G. Zalman. 1997. Gibberellic acid sprays for improving fruit peel quality and increasing juice yield of processing oranges. Proc. Fla. State Hort. Soc. 110: $16-21$.

Davies, F.S., C.A. Campbell, G. Zalman, and M. Fidelibus. 1999. Gibberellic acid application timing effects on juice yield and peel quality of 'Hamlin' oranges. Proc. Fla. State Hort. Soc. 112:22-24.

Davies, F.S. and G.R. Zalman. 2001. Nitrogen, rootstocks, and growth of young 'Rhode Red' valencia orange trees. HortScience 36: 62-65.

Davies, F.S. and G.R. Zalman. 2004. Fruit quality sampling of 'Valencia' orange trees. Proc. Fla. State Hort. Soc. 117:86-88.

Davies, F.S. and G.R. Zalman. 2006. Gibberellic acid, fruit freezing, and post harvest freeze quality of 'Hamlin' oranges. HortTechnology 16:301-305.

El-Otmani, M., C.W. Coggins, M. Agusti, and C.J. Lovatt. 2000. Plant growth regulators in citriculture: World current uses. Crit. Rev. Plant Sci. 14:367-412.

Fidelibus, M.W., A.A. Teixeira, and F.S. Davies. 2002. Mechanical properties of orange peel and fruit treated pre-harvest with gibberellic acid. Trans. ASAE 45:1057-1062.

Hendershott, C.H. 1962. The responses of orange trees and fruits to freezing temperatures. Proc. Amer. Soc. Hort. Sci. 80:247-254.

Rasmussen, G.K., C.J. Hearn, and W.C. Cooper. 1963. Biweekly changes in quality of fruit on Valencia orange trees caused by the Dec. 1962 freeze in Florida. Proc. Fla. State Hort. Soc. 76:94-97.

Reitz, H.J. and J.W. Sites. 1948. Relation between position on the tree and analysis of citrus fruit with special reference to sampling and meeting internal grades. Proc. Fla. State Hort. Soc. 61:80-90.

Syvertsen, J.P. 1982. Dehydration of freezedamaged oranges. HortScience 17:803-804.

Wardowski, W., J. Soule, W. Grierson, and G. Westbrook. 1995. Florida citrus quality tests. SP99. Inst. Food and Agr. Sci., Univ. of Fla., Gainesville, Fla.

Young, R. 1971. Effect of growth regulators on citrus seedling cold hardiness. J. Amer. Soc. Hort. Sci. 96:708-710.

Wilcox, D.A. and F.S. Davies. 1981. Modification of citrus leaf and air temperatures with high volume under-tree sprinklers. Proc. Fla. State Hort. Soc. 94:59-63. 